\title{
Working
}

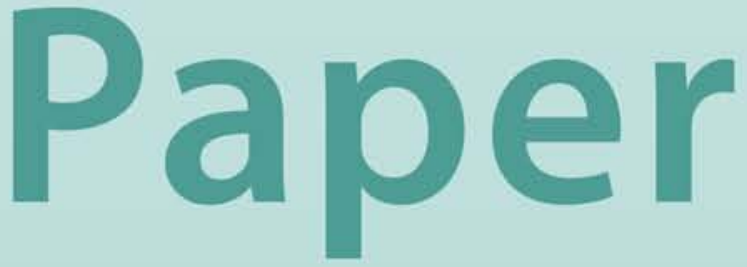




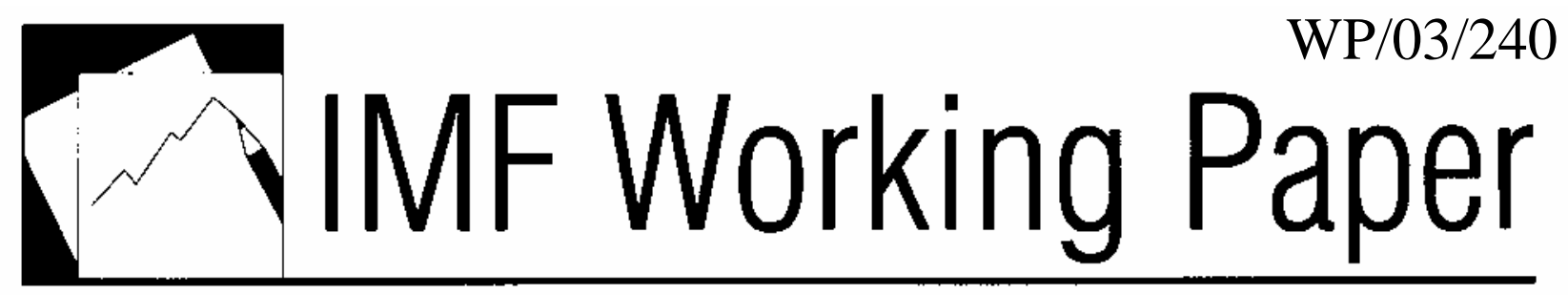

Patterns of Shocks and Regional Monetary Cooperation in South Asia

Nephil Matangi Maskay 


\title{
IMF Working Paper
}

\author{
IMF Institute
}

\section{Patterns of Shocks and Regional Monetary Cooperation in South Asia}

\author{
Prepared by Nephil Matangi Maskay ${ }^{1}$
}

Authorized for distribution by Saleh M. Nsouli

December 2003

\begin{abstract}
This Working Paper should not be reported as representing views of the IMF. The views expressed in this Working Paper are those of the author(s) and do not necessarily represent those of the IMF or IMF policy. Working Papers describe research in progress by the author(s) and are published to elicit comments and to further debate.
\end{abstract}

The member states of the South Asian Association for Regional Cooperation have set as a target the achievement of an economic union by 2020. Reaching this goal will require greater levels of monetary cooperation. How should this be achieved? Data from South Asia suggest that member states have minor trade linkages and face asymmetrical patterns of shocks. This paper concludes that, absent a clear road map for monetary cooperation, the present process must be structured so as to be harmonized with the level of regional economic integration.

JEL Classification Numbers: F3, F4

Keywords: South Asia, shocks, regional monetary cooperation

Author’s E-Mail Address: nmmaskay@nrb.org.np

\footnotetext{
${ }^{1}$ Part of the research for this paper was done while the author was an IMF Visiting Scholar under the Global Development Network (GDN) program at the IMF Institute in Washington, D.C., while on leave from Nepal Rastra Bank. He would like to thank Woon Gyu Choi, Joshua Greene, Gene Leon, Catriona Purfield, Enric Fernandez, and Geoffrey Heenan for helpful comments. Standard disclaimers apply; the views expressed in the paper are solely those of the author and are not necessarily the views of Nepal Rastra Bank or of any other author-associated institutions.
} 


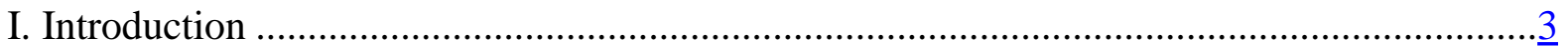

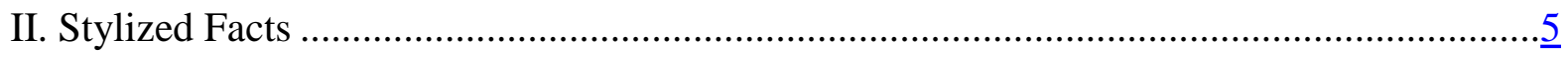

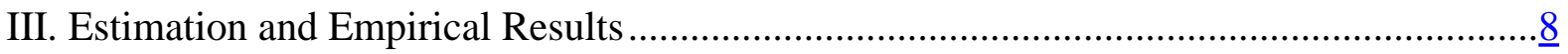

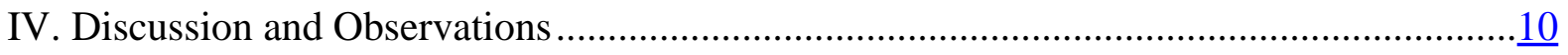

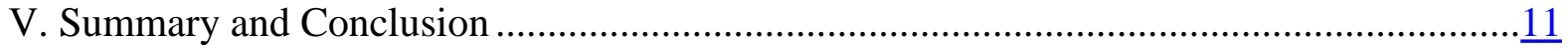

Tables

1. Characteristics of SAARC Member States .............................................................. $\frac{13}{14}$

2. Macroeconomic Indicators of SAARC Member States $(1980-2000)$...............................14

3. Regional Trade Patterns ................................................................................... $\frac{15}{16}$

4. Exchange Rate Correlations of SAARC Member States (1980-2000) ..........................16

5. Nominal Effective Exchange Rate Correlations of SAARC Member States ...................16

6. Real Effective Exchange Rate Correlations of Bangladesh, India, Nepal,

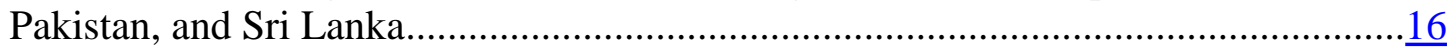

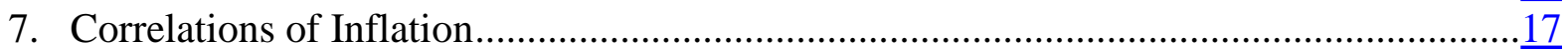

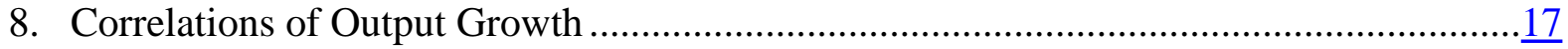

9. Correlations and Standard Deviations of Disturbances (single lag) ...............................18

10. Correlations and Standard Deviations of Disturbances (double lag) .............................. 18

Figures

1. Nominal Exchange Rates of the SAARC Member States vis-à-vis the U.S. Dollar ............19

2. Growth Rates of the Nominal Exchange Rates of the SAARC Member

States vis-à-vis the U.S. Dollar ............................................................................... 20

3. Nominal Effective Exchange Rates of the SAARC Member States................................. $\frac{21}{22}$

4. Real Effective Exchange Rates of Bangladesh, India, Nepal, Pakistan, and Sri Lanka .......22

5. Inflation Rates of SAARC Member States .............................................................. 23

6. Output Growth Rates of SAARC Member States......................................................

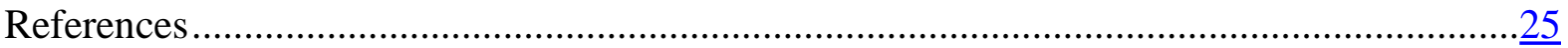




\section{INTRODUCTION}

Interest in greater regional economic and monetary integration, fueled partly by the achievement of an economic union and a single currency in Europe, has grown in different parts of the world. This includes South Asia (SA) and the regional organization known as the South Asian Association for Regional Cooperation (SAARC), which has announced the goal of attaining an economic union and expressed the desire for a common currency. This paper uses economic data to assess the desirability of greater monetary cooperation in South Asia.

SAARC is a fairly recent association, established in 1985 by the seven member states of Bangladesh, Bhutan, India, Maldives, Nepal, Pakistan, and Sri Lanka (SAARC, 1985). These seven countries differ greatly in land area, GDP, and population, although they have similar levels of human and economic development. They also share the unusual feature of having a common border with only one other member country: India (see following section as well as Khan and Khan (2003)). While some cooperation among the member states has taken place since 1980, structured economic cooperation began only in December 1995, with the implementation of the SAARC Preferential Trading Agreement (SAARC website). However, from then through end-2000, the most recent period for which data are available, intra-SAARC trade did not accelerate and was only 3.8 percent of the region's total trade, reflecting limited intraregional factor mobility.

Despite this situation, the member states have expressed a desire for higher levels of economic cooperation, as stated in the declaration at the eleventh SAARC Summit, held in Katmandu in January 2002 (SAARC, 2002, Para 1), for a South Asian Economic Union (SAEU). The SAARC Group of Eminent Persons (GEP) report (SAARC, 1997/98, pp. 2021) has in turn provided a roadmap toward economic integration: a South Asian Free Trade Area, a South Asian Customs Union in 2015, and SAEU by 2020. While explicit preconditions for each stage of integration have not been specified, the broad roadmap and milestones have been suggested. It is hoped that closer economic integration and an SAEU will accelerate economic growth, promote the welfare of South Asian citizens, and improve their quality of life.

The solidarity reflected in the above statements is noteworthy. However, the reality is very different. There is regional turbulence, largely reflected in the hostility between the two largest members of SAARC, India and Pakistan. The hostility between these two countries dates back to their independence in 1947, with a number of conflicts that continue to the present day. This situation has hindered the process of economic integration and weakened the political commitment toward regional integration, as evidenced by missing the deadline for the draft treaty framework of the South Asian Free Trade Area and postponing the twelfth SAARC Summit. ${ }^{2}$ While the absence of political unity delays movement toward SAEU,

${ }^{2}$ It is important to point out that political commitment mattered greatly for the push to European Monetary Union and is a driving force in the Association of South East Asian Nations (ASEAN). 
observers still expect that in the long term, SAEU will be achieved. This expectation remains plausible, not only because of the perceived benefits of closer economic integration, as mentioned above, but also because of fears that the SA region will otherwise be "marginalized" in the face of growing regional integration elsewhere. ${ }^{3}$ Thus it is important to highlight the processes that will facilitate greater levels of regional economic integration.

Monetary cooperation has been widely acknowledged as a way to smooth progress toward economic integration, ${ }^{4}$ since it provides a stable financial environment that can promote greater regional trade, ${ }^{5}$ helping stabilize regional exchange rates and reduce uncertainty in their movements. This may be particularly beneficial for SA, which lacks mature future markets in foreign exchange. The importance of a stable financial environment has been acknowledged by the SAARC GEP report (SAARC, 1997/98, p. 21) which, in addition to SAEU, has also mentioned the goal of achieving a "single monetary system, including a common currency." However, this last goal has not been elaborated in the same detail as done earlier for economic integration, ${ }^{6}$ perhaps because of the politically sensitive nature of national currencies, which evoke strong attachment and emotion. While movement toward greater monetary cooperation need not occur immediately, information highlighting aspects of how to achieve it is critical, both to understand the processes for achieving cooperation and to minimize the risks of derailing regional economic integration.

The objective of the paper, therefore, is to present some preliminary information relevant to this analysis, on the pattern of economic shocks affecting the member economies in the region. A finding of similarity of economic disturbances among member countries will support the idea of a currency union and greater monetary cooperation, as there would be less need for monetary policy to undertake adjustment. This information will be helpful in designing the process for achieving higher levels of monetary cooperation in SA. The paper concludes that the appropriate process of monetary cooperation in SA should be harmonized

\footnotetext{
${ }^{3}$ There are many examples, such as in the 1997/98 SAARC GEP report.

${ }^{4}$ This would entail greater coordination of monetary and exchange rate policy, and is analogous to higher levels of monetary integration, as discussed in Tavlas (1994).

${ }^{5}$ There is general agreement that a stable financial environment has a positive effect on trade, which may be more so in SA given the absence of a mature futures market to hedge against exchange rate risk. The magnitude of this benefit is still being debated, although Rose (2000) has stated that the effect of a currency union on international trade is "three times as much as it would be with different currencies."

${ }^{6}$ Interestingly, the logic and phases of economic integration (i.e., from a South Asian Free Trade Area to a South Asian Customs Union to SAEU) had been covered in great detail in SAARC (1997/98) over a number of pages; contrast this to a common currency, which is mentioned only in a single sentence.
} 
with the level of regional economic integration, which presently is limited, using the interim period to develop a comprehensive and integrated plan for this objective.

The outline of the paper is as follows. Section II provides some stylized facts on the SA region. Section III examines the economic data, using standard analysis of patterns of shocks. Section IV presents some discussion and observations, while Section V concludes.

\section{STylized FACTS}

This section describes some stylized facts about the SA region, including the exchange arrangements of member countries and their growth and inflation performance. Table 1 provides some basic data about the seven member states of SAARC. Table 1 confirms that these countries are diverse in terms of land area, GDP, and population, while having similar levels of human and economic development. For example, India is more than ten thousand times larger, three thousand times more populous, and has GDP over eight hundred times greater than the smallest country in SAARC, Maldives. However, the member states have similar values for GDP per capita (PPP, in U.S. dollars) and indicators of development (HDI). ${ }^{7}$

Table 2 shows the trends of regional economic indicators (inflation, government deficit and debt burden, and output growth) for the period 1980-2000. ${ }^{8}$ Average inflation is higher than in the Euro Area but less than in the ASEAN region. However, the average government deficit in SAARC is higher than in both the ASEAN and the Euro areas (Bayoumi and Mauro, 2001), ${ }^{9}$ while the growth rate is comparable to that in ASEAN (Bayoumi and Eichengreen, 1994). ${ }^{10}$ SAARC is also relatively closed in terms of trade. Table 3 shows that intra-SAARC trade was less than 4 percent of regional income in 2000, mainly involving primary products (RIS, 2002) ${ }^{11}$ while trade with countries outside the

\footnotetext{
${ }^{7}$ The similarity of SAARC economic and human development is further reflected by four of the member states (Bangladesh, Bhutan, Maldives and Nepal), which are Least Developed Countries, while the remaining three are developing countries.

${ }^{8}$ This time span was chosen since it generally captures all the SAARC member states. The spans for Bangladesh, Bhutan, India, Maldives, Nepal, Pakistan, and Sri Lanka price series are 1973-2001, 1980-2000, 1950-2001, 1974-2001, 1960-2001, 1953-2001, and 19502000, respectively, while the respective spans for output are 1973-2001, 1980-2000, 19502000, 1974-2001, 1960-2001, 1953-2001, and 1950-2000.

${ }^{9}$ The time span used is $1988-1997$.

10 The time span used is 1969-1989.

${ }^{11}$ The present nature of primary intra-regional trade does not provide much advantage, assuming an exogenously (i.e., globally) determined price.
} 
region (i.e., regional trade openness) was limited to 25 percent of regional income. This trade pattern compares poorly with the ASEAN and Euro areas, while being similar to that for Mercosur and NAFTA (Bayoumi and Mauro, 2001). Another key feature of SAARC is the significant role of India in the region, which changes the dynamics of interaction among members. India has 72.58 percent of the land area, 78.98 percent of the GDP, and 75.49 percent of the population of SAARC as a whole. ${ }^{12}$ This needs to be seen not only in terms of India's physical and economic size, but also its geographical location, making it 'central' to the SA region.

Just as there is huge diversity among the member states, there is diversity in their exchange rate regimes. India, Sri Lanka ${ }^{13}$ and Pakistan all have a managed float, while Bangladesh, Bhutan, Maldives, ${ }^{14}$ and Nepal have a pegged exchange rate (IMF, IFS, 2002). The peg of the Bhutan and Nepalese currencies to the Indian rupee is fairly rigid, with oneto-one convertibility for the Bhutanese ngultrum over the last twenty years and only three adjustments (the last being almost ten years ago) in the exchange rate between the Indian and Nepalese rupees. Exchange rate data also suggest that Maldives has a form of pegged arrangement to the U.S. dollar, since it has maintained a rigid exchange rate to the dollar during the last five years of the sample period. Figures 1,2 and 3 show the exchange rates of the member states vis-à-vis the U.S. dollar and their nominal and real effective exchange rates (NEER and REER respectively) ${ }^{15}$ over the period of 1980-2000. The first figure shows a similarly depreciating trend of for every currency except that of the Maldives, which has had periods of no change vis-à-vis the U.S. dollar. The rates of nominal depreciation in these exchange rates are given in the second figure, where eyeballing suggests the same movement of the Bhutanese, Indian, and Nepalese currencies, but not for other currencies. This observation, that the three currencies have moved similarly vis-à-vis the U.S. dollar, is consistent with the three pairs of bilateral exchange rates having a coefficient of correlation of greater than 85 percent, along with the absence of any such correlation among the bilateral exchange rates of the remaining currencies (Table 4). Looking at Figures 4 and 5 for NEER and REER likewise shows a similar, generally decreasing trend over the time period, although the REER for Sri Lanka suggests that there has not been any trend in the movement

${ }^{12}$ By comparison, no one country has the same weight in the European Union as does India in SAARC. In Europe, in 1993, German GDP was greater by 50\% than France, while in SA in 2000, Indian GDP was almost seven and a half times larger than the next largest country, Pakistan.

${ }^{13}$ Since January 2001, Sri Lanka's exchange rate has been characterized as a free float.

${ }^{14}$ IFS Yearbook 2002, pp. 4-5, in the table entitled "Exchange Rate Regimes and Anchors of Monetary Policy," notes in a footnote that the de facto regime differs from the de jure regime for Maldives.

15 The data for NEER and REER are courtesy of the IMF. 
over the sample period. The observation of similarity in movement in the NEER and REER is confirmed by examining the correlations in Table 5 and 6 , with all being positive-this may reflect similarity in trading patterns of South Asia members. ${ }^{16}$ The management of SAARC exchange rates is discussed in greater detail in NRB (2001).

The summary statistics of inflation and output growth for SAARC member countries, reported earlier in Table 2, also suggest broad similarity among six of the seven countries. Inflation averaged between 8 and 9 percent, except for Bangladesh and Maldives, where it averaged 6.8 and 6.7 percent, respectively. Real output growth averaged 4 to 6 percent, except for Maldives, where it averaged 8.4 percent. However, plots of inflation and real growth rates, reported in Figures 5 and 6, suggest no clear trend in either series over the period. This observation is consistent with the data reported in Tables 7 and 8 on correlations of inflation and growth rates among the countries. These figures show both positive and negative correlations for inflation and growth rates between individual member countries. ${ }^{17}$

It is not sufficient to look only at the signs of the above correlations. One must also examine their statistical significance. Using the 5 percent significance level as the cut off, statistical significance requires a 43 percent coefficient of correlation, given the limited number of observations. ${ }^{18}$ The significant correlations are highlighted in Tables $4-8$. The observation of a smaller regional grouping of the three currencies is statistically significant at the 5 percent level, while there appears no significant correlation in the bilateral exchange

${ }^{16}$ Member states of the SAARC region appear to face a common external shock (see Cerra and Saxena (2000) for the Indian case, etc.), as evidenced by their experiencing a crisis in the balance of payments mirrored in extreme volatility in the exchange rates during the 1990s (see NRB, 2001). Moreover, five of the seven member states accepted IMF Article VIII status during the period around mid-1994 (Bangladesh: April 11, 1994; India: August 20, 1994; Nepal: May 30, 1994; Pakistan: July 1, 1994; Sri Lanka March 15, 1994.

Subsequently, these five countries observed closer exchange rate movements, as indicated by positive correlations in their exchange rates (see Table 4.) Bhutan and Maldives, however, have yet to accept Article VIII status.

${ }^{17}$ A further observation can be made that the band of inflation is generally small for SAARC countries, where there has been a decreasing trend in inflation in the period 1994-2000 vis-àvis 1981-1993, from an average rate of 9.2 percent inflation in the earlier period to 6.4 percent in the latter. This is in line with the global trend of a slowing in inflation.

${ }^{18}$ The formula $Z=\frac{1}{2} \sqrt{N-3}\{\ln [(1+r)(1-\rho) /(1-r)(1+\rho]\}$ is used to test the significance of correlations (Romano 1970: 156-160), with $H_{0}: \rho=0$ versus $H_{A}: \rho \neq 0$, using $\alpha=0.05,0.01$. The rejection region is $Z=\left|\frac{1}{2} \sqrt{N-3}\{\ln [(1+r) /(1-r)]\}\right|>1.96,2.58$. 
rates of the remaining currencies (Table 4). This observation remains true for the NEER of the three countries and the REER of Nepal and India (REER data were not available for Bhutan), with a large number of significant correlations in both NEER (Table 5 with six of a possible fifteen) and the REER (Table 6 with four of a possible ten). Similar to the description of the nominal exchange rate, Tables 7 and 8 show only a handful of significant correlations from the twenty-one possible correlations for inflation and growth. The correlations show no significant similarity in the movement of these variables: some are positive, while others are negative.

\section{ESTIMATION AND EMPIRICAL RESUlTS}

The paper uses one particular aspect of the criteria for determining Optimum Currency Areas (OCA) ${ }^{19}$ - the pattern of shocks facing a set of countries-to determine if they are candidates for a currency union. ${ }^{20}$ The patterns of shocks facing a group of countries indicate the cost of losing the tools of monetary and exchange rates for adjustment. Countries that face similar shocks would likely encounter lower costs in giving up these tools of adjustment than would other sets of countries facing economic shocks. ${ }^{21}$

A number of estimation techniques attempt to measure the pattern of underlying disturbances a region faces. ${ }^{22}$ Unfortunately, preliminary estimates suggest that the data for a number of the member states would not allow using the VAR technique, which decomposes shocks from responses and allows analyzing the size of the disturbance and the speed of

${ }^{19}$ OCA originated in the seminal paper of Mundell (1961), where the author defined the appropriate geographical domain of a currency area as a "domain within which exchange rates are fixed" against each other although flexible vis-à-vis the outside world, so that the exchange rate would maintain external equilibrium without causing inflation or unemployment. Since then, many different criteria have been introduced for candidacy in a common currency area (for a recent discussion see Willett (2002)).

${ }^{20}$ While there are many OCA criteria, viz. openness, labor mobility, etc., pointing to the choice of the optimal exchange rate, Masson and Taylor (1993, p. 17) comment that "shockabsorption combines the net influence of several traditional criteria." This property eliminates the problems of individual OCA criteria putting forward conflicting policy prescriptions about the country's optimal exchange rate policy. Thus, patterns of shocks may be the best OCA criteria pointing toward optimal exchange rate policy.

${ }^{21}$ Contrast this approach with the automatic stabilizer perspective, which identifies countries with different economic disturbances as candidates to partner for a fixed exchange rate regime.

${ }^{22}$ See Bayoumi and Eichengreen (1994) and citations therein. 
adjustment. ${ }^{23}$ For this reason, and to allow comparison across the region, a simpler time series model of growth was used, where the growth of real output was regressed upon its own lags. ${ }^{24}$ Both one- and two-period lags were used, since the data could not produce a consensus optimal lag length, ${ }^{25}$ with the residuals taken to represent the underlying disturbances.

Running the above regression provides a time series of disturbances for SAARC member countries. Tables 9 and 10 show the correlations of those disturbances with a single and double lag. The results are similar to the prior examination of correlation coefficients in Table 8. Again there is no clear-cut pattern of disturbances, as seen from the large number of both positive and negative correlation coefficients. Quite a few correlations are significant at the 5 percent level, more with the single than the double lag, but there is no consistency in either the positive or the negative direction. ${ }^{26}$ This suggests that the member states did not face symmetric patterns of shocks during that time period. This is similar to a finding for Africa (Bayoumi and Ostry, 1997). However, the results compare poorly with those for East Asia and Western Europe, which have a large number of positively significant aggregate supply shocks (Bayoumi and Mauro, 2001). It is also important to examine the volatility of real shocks, taken as the standard deviation of the residuals above, that SAARC member countries face. ${ }^{27}$ The descriptive statistics of the standard deviation of the errors appear in Tables 9 and 10. The standard deviations of the errors for both lags are similar to the results of Bayoumi and Eichengreen (1994) calculated for Germany, Japan, and United States: they are in the 2 percent range. On the other hand, the results for Maldives are similar to those for Africa (Bayoumi and Ostry, 1997), which fall into the 3 percent-4 percent range for the second lag.

${ }^{23}$ Preliminary estimation suggests that the data could not be analyzed using the VAR approach of Bayoumi and Eichengreen (1994), which differentiates supply and demand shocks. This result is consistent with Maskay (1998). This conclusion resulted because the impulse response functions had perverse price responses to supply shocks - the price levels increased with a positive demand shock (true for Bhutan, Maldives, and Nepal). The impulse response functions of the different series are not included, to save space, and are available on request.

24 This had been used by Bayoumi and Ostry (1997), who faced the same difficulty with data from Africa.

${ }^{25}$ From both the Akaike and Schwarz criteria.

${ }^{26}$ This result is similar to Maskay (2002), who looks at an earlier period.

${ }^{27}$ Kontohemis and Samiei (2000) use the variance of GDP growth to assess volatility. 


\section{DiSCUSSION AND OBSERVATIONS}

The empirical results show that the region is not a suitable candidate for a currency union. The member states do not face symmetric economic shocks, suggesting that they are more likely to have to adjust against each other than against a common external partner. Underscoring this empirical observation is the low level of economic integration in SA, reflected in the limited level of intra-SAARC trade and low intra-regional factor mobility. These factors suggest a large cost to the adjustment process (which is also consistent with NRB (2000)). More importantly, the regional political commitment to establishing a currency union is missing. Thus, the absence of both the economic and political justifications argue against the immediate consideration of the highest level of monetary cooperation, i.e., a currency union.

It is natural to ask if the empirical results point to smaller regional currency groupings in SAARC. Here the results indicate some paradoxical conclusions. For example, the positive correlations for disturbances in Pakistan and India (significant in the first lag but not in the second lag) suggest these two countries as candidates for a currency union. However, the miniscule bilateral trade and virtual absence of factor inter-linkages, not to speak of the ongoing tension, suggest otherwise. On the other hand, Bhutan and Nepal, which each have a fixed exchange rate with the Indian rupee, appear to face statistically insignificant disturbances (some are even negative) with India, suggesting that neither country would be a candidate for a currency union with India. These observations for Nepal and Bhutan are contrary to the similar economic performance and significant bilateral trade and factor interlinkages between each country and India. While the empirical results do not point to alternative regional groupings, they reiterate the conclusion of Maskay (2000) that a broader analysis is required to determine optimal exchange rate policy, not limited to a single criterion (in this case, patterns of shocks). ${ }^{28}$

While the data suggest that the member states in SA may not be candidates for a currency union during the sample period, the results would certainly change with greater economic integration, as envisaged by SAEU. This is simply stating that the cost for joining a currency union is endogenous over time (Frankel and Rose, 1998; also Karras and Stockes, 2001). Since the SAARC GEP (1997/98) envisions SAEU as a long-term goal, to be achieved at the earliest by 2020 , this suggests that the cost for monetary cooperation would decrease with higher levels of economic integration. The long time horizon also makes sense in view of the present turbulent situation in SA. The implication is that steps toward

${ }^{28}$ As noted earlier, however, the data show Maldives as having economic performance (in terms of exchange rate performance, average inflation, and output growth) during the period different from other member states in SAARC, despite significant intra-SAARC trade of 38 percent in 2000. This experience largely reflects the economic structure of Maldives as an island nation. It is also important to note that Maldives is geographically the most distant, and the smallest, of all the SAARC member states. 
monetary cooperation should continue at a cautious pace. In this regard, some important developments have taken place recently, with the establishment and formal recognition in the last SAARC summit of SAARCFINANCE, an organization of Governors of Central Banks and Secretaries of Finance of SAARC member states (for SAARCFINANCE terms of reference, see SAARC home page). Presently, the activities of this organization are limited to information sharing, staff visits, and organizing workshops/seminars.

It is also important to be aware of the sequencing used to achieve monetary cooperation. Unfortunately, SAARC GEP (1997/98) has not given a time bound road map with clear preconditions for attaining greater monetary cooperation. This is in contrast to economic integration, where the stages are mentioned in relatively greater detail. While the path for monetary cooperation will have to be assessed more comprehensively, movements toward monetary and economic integration may not stray too far from each other. Thus, it would seem reasonable, until a detailed framework is developed, for monetary cooperation to draw on the road map for economic integration as put forth above, to harmonize the respective monetary policies of member states consistent with their level of economic integration.

\section{SUMmARY AND CONCluSION}

This paper has examined the patterns of shocks in SA, to assess the grounds for increasing monetary cooperation. The empirical analysis suggests that member states were not suitable candidates for a currency union during the period surveyed, since they were prone to asymmetrical economic disturbances with large adjustment costs and exhibited low economic (i.e., trade and factor) integration. The empirical results thus suggest that the sequence of monetary cooperation in SA should be structured and harmonized with the level of regional economic integration. ${ }^{31}$

While the above results suggest that the region is not suitable for a currency union at this time, greater economic integration will reduce the cost of monetary cooperation.

Moreover, the nature of shocks that strike the developing member economies in SA will also change over time. Economic development and the declining share of agriculture to GDP will make economic performance less sensitive to agriculture shocks. At the same time, as the region moves to an SA free trade area and the level and diversity of intraregional trade flows increase, terms of trade and financial shocks will become more likely. Other points also need

${ }^{31}$ The present activities of SAARCFINANCE, as mentioned above, are consistent with this. 
to be considered, ${ }^{32}$ detailed discussion of which is beyond the scope of this paper. Thus, the complexity of this issue highlights the need for a comprehensive and integrated plan regarding monetary cooperation in SA, including the necessary preconditions. ${ }^{33}$ In the interim, the activities of SAARCFINANCE may be considered the start for greater monetary cooperation in the region. SAARCFINANCE may also be able to begin preliminary work for developing a comprehensive and integrated road map toward greater cooperation, which would not be inconsistent with the broad objectives of the organization (as stated in its Terms of Reference). Doing so would also be consistent with Dasgupta and Maskay (2003).

This paper ends by reflecting on the absence of political commitment to integration in SA. The political aspect, while harder to quantify, may be the most important ingredient. ${ }^{34}$ Thus, priority should be given to greater interaction under the SAARC process, to enhance understanding among members and develop the feeling of regional identity. In other words, the political component is likewise endogenous. In my view, this component is of critical importance, since sustainable political commitment is the necessary and perhaps sufficient condition for higher levels of economic integration and monetary cooperation.

32 These include the factors highlighted in Masson and Patillo (2001) regarding preconditions and operationalization.

${ }^{33}$ Of course, the end product of greater monetary cooperation and a single SA monetary system should be debated: should it be a common currency, as mentioned in SAARC (1997/98) (i.e., a new currency, as in Europe, or a currency of one member state), or some other variation?

34 This was highlighted in Minz (1970) and may most saliently be seen in the process of monetary union in Europe. 
Table 1. Characteristics of SAARC Member States

\begin{tabular}{lrrrrr}
\hline & $\begin{array}{c}\text { Area } \\
\text { (sq. mile) }\end{array}$ & $\begin{array}{c}\text { GDP } \\
\text { (USD mill.) } \\
2000\end{array}$ & $\begin{array}{c}\text { Population } \\
\text { (mil.) }\end{array}$ & $\begin{array}{c}\text { GDP per } \\
\text { capita (PPP, }\end{array}$ & $\begin{array}{c}\text { HDI } \\
\text { Value }\end{array}$ \\
\hline Bangladesh & 56,977 & 47,106 & 140.37 & 1,602 & 0.478 \\
Bhutan & 18,150 & $482^{*}$ & $2.09^{*}$ & 1,412 & 0.494 \\
India & $1,222,243$ & 456,970 & $1,017.54$ & 2,358 & 0.577 \\
Maldives & 115 & $561^{*}$ & 0.28 & 4,485 & 0.743 \\
Nepal & 53,827 & 5,497 & 23.59 & 1,327 & 0.490 \\
Pakistan & 307,374 & 61,638 & 144.97 & 1,928 & 0.499 \\
Sri Lanka & 25,332 & 6,305 & 19.10 & 3,530 & 0.741 \\
SAARC & $1,684,014$ & 578,559 & $1,347.94$ & $\ldots$ & $\ldots$ \\
\hline
\end{tabular}

Source: For the first column: The World Almanac and Books of Facts 1998; for the second column, GDP at producer prices, using the average exchange rate from the IMF, as reported in World Development Indicators 2002; “*” indicates author's own calculations from International Financial Statistics, using GDP (IFS code 99b), and average exchange rate visà-vis the USD (IFS code rf); for the third column, population (IFS code 99z) from IFS

Yearbook 2002; the values for GDP per capita for purchasing power parity (PPP) in 2000 and Human Development Index (HDI) are taken from Human Development Report 2002. 
Table 2. Macroeconomic Indicators of SAARC Member States (1980-2000)

(in percent change or percent of GDP)

\begin{tabular}{lcccc}
\hline \multicolumn{1}{c}{ Country } & Inflation & $\begin{array}{c}\text { Average Government } \\
\text { Balance }\end{array}$ & $\begin{array}{c}\text { Government } \\
\text { Debt/GDP }\end{array}$ & $\begin{array}{c}\text { Output } \\
\text { Growth }\end{array}$ \\
\hline Bangladesh 2/ & 6.8 & $0.501 *$ & & \\
Bhutan & 8.3 & $-2.011 * *$ & $\ldots$ & 4.3 \\
India & 8.2 & -6.43 & $\ldots$ & 6.5 \\
Maldives 3/ & 6.7 & -.000063 & 45.0 & 8.6 \\
Nepal & 9.4 & $-0.56294 * * *$ & 53.0 & 4.6 \\
Pakistan & 8.1 & $-6.953^{*} * * *$ & $\ldots$ & 4.9 \\
Sri Lanka 4/ & 9.9 & -9.261 & 97.0 & 4.6 \\
& & & & \\
Average & 8.3 & $-5.25 * * * * *$ & $66.05 /$ & 5.7 \\
ASEAN Average 6/ & 20.2 & -0.8 & $38.07 /$ & $\ldots$ \\
Euro Area Avg. 6/ & 3.4 & -4.1 & $69.07 /$ & $\ldots$ \\
\hline
\end{tabular}

Source: 1. Inflation is taken as the log change of the deflator for Gross Domestic Product (GDP) (IFS code f99bi.p), with exceptions noted as below. 2. Average government deficit is taken as the ratio of central government deficit (IFS code 80) to GDP (IFS code 99b). For * data are available only for 1980-85; for ** data for 1980, 1981 and 1987 are not available; for *** data for 2000 are not available; **** for Pakistan, Federal Government deficit for 2000 is taken from IMF Country Report No. 02/247; ***** average of available data of India, Maldives, and Sri Lanka only. 3. Government debt is taken as the sum of domestic debt (IFS code 88) and foreign debt (IFS code 89) with *** and **** as earlier. 4. Output growth is taken as the log change in real GDP (IFS code f99b.p), with exceptions noted below.

NOTES: 1. Data were taken from IFS Yearbook 2002 unless otherwise noted.

2. There is a spike in Bangladeshi inflation during 1989/90 which is inconsistent with analysis of Hossain (2002) and IMF; because of this data were taken from the Bangladesh Bureau of Statistics, which had a 95\% fit for the period of 1986-2000 excluding 1989/90. Thus, movements for 1989/90 have been obtained from the earlier mentioned data. 3. For Maldives, no GDP deflator information was available for 1982 and 1983. Thus, data for GDP were projected from GDP Volume at 1994 prices (IFS code 99b.p; 99\% fit) and total fish catch (IFS code 66a1; 93\% fit).

4. Data for Sri Lanka during the period 1996-2000 were taken from IFS Yearbook 2001.

5. Average for 2000.

6. Data are averages for 1988-97, taken from Bayoumi and Mauro (2001).

7. Average for 1997, from Bayoumi and Mauro (2001). 
Table 3. Regional Trade Patterns

\begin{tabular}{lcc}
\hline & $\begin{array}{c}\text { Intra }- \text { SAARC } \\
\text { Trade }\end{array}$ & Openness \\
\hline Bangladesh & $7.8 \%$ & $31.78 \%$ \\
Bhutan & $\ldots$ & $\ldots$ \\
India & $2.5 \%$ & $21.26 \%$ \\
Maldives & $\ldots$ & $80.28 \%$ \\
Nepal & $31.3 \%$ & $44.46 \%$ \\
Pakistan & $2.5 \%$ & $31.41 \%$ \\
Sri Lanka & $6.4 \%$ & $73.01 \%$ \\
SAARC & $3.8 \%$ & $25.89 \%$ \\
& & \\
\hline
\end{tabular}

\begin{tabular}{ccc} 
Organization & Intra & Openness \\
\hline $\begin{array}{c}\text { SAARC } \\
(\mathbf{2 0 0 0 )}\end{array}$ & $3.8 \%$ & $25.89 \%$
\end{tabular}

\begin{tabular}{ccc}
$\begin{array}{c}\text { ASEAN } \\
(\mathbf{1 9 9 8})\end{array}$ & $23.5 \%$ & $101.2 \%$ \\
$\begin{array}{c}\text { Euro Area } \\
(\mathbf{1 9 9 8})\end{array}$ & $24.8 \%$ & $50.8 \%$ \\
\hline
\end{tabular}

\begin{tabular}{ccc}
$\begin{array}{c}\text { Mercosur } \\
\text { (1998) }\end{array}$ & $4.4 \%$ & $18.1 \%$ \\
$\begin{array}{c}\text { NAFTA } \\
\text { (1998) }\end{array}$ & $10.7 \%$ & $23.9 \%$ \\
\hline
\end{tabular}

Source: Data for intra-SAARC trade for member states are from Direction of Trade Statistics Yearbook 2001. Data for openness are total merchandise trade from IFS, with dollar value (converted at average period exchange rate against dollar (rf)) as a percent of GDP. The data for regional groupings of ASEAN, Euro Area, Mercosur, and NAFTA are taken from Bayoumi and Mauro (2001).

Note: The high level of Nepalese trade with India is due to the free trade agreement shared between both countries, which accounted for 30.8 percent of intra-SAARC trade. The data for Bhutan and Maldives were not found in Direction of Trade Statistics Yearbook 2001. However, given the size of those countries, it is not expected to make much difference to the SAARC average. 
Table 4. Exchange Rate Correlations of SAARC Member States (1980-2000)

\begin{tabular}{|c|c|c|c|c|c|c|c|}
\hline & GRBAN & GRBHU & GRIND & GRMAL & GRNEP & GRPAK & GRSRI \\
\hline GRBAN & 1.000000 & & & & & & \\
\hline GRBHU & -0.020310 & 1.000000 & & & & & \\
\hline GRIND & -0.020310 & 1.000000 & 1.000000 & & & & \\
\hline GRMAL & -0.318082 & -0.123604 & -0.123604 & 1.000000 & & & \\
\hline GRNEP & 0.181695 & 0.878744 & 0.878744 & -0.183786 & 1.000000 & & \\
\hline GRPAK & 0.061843 & 0.271474 & 0.271474 & -0.335429 & 0.257429 & 1.000000 & \\
\hline GRSRI & -0.110254 & 0.189276 & 0.189276 & 0.038908 & 0.054980 & -0.037991 & 1.000000 \\
\hline
\end{tabular}

Source: IFS code ae (end-of-period exchange rate in units of national currency to the U.S. dollar).

Table 5. Nominal Effective Exchange Rate Correlations of SAARC Member States

\begin{tabular}{lcccccc}
\hline & GRBAN & GRBHU & GRIND & GRNEP & GRPAK & GRSRI \\
\hline & & & & & & \\
GRBAN & 1.000000 & & & & & \\
GRBHU & 0.235620 & 1.000000 & & & & \\
GRIND & 0.339918 & 0.861083 & 1.000000 & & & \\
GRNEP & 0.405345 & 0.571886 & 0.610145 & 1.000000 & & \\
GRPAK & 0.547450 & 0.312159 & 0.426551 & 0.453633 & 1.000000 & \\
GRSRI & 0.595279 & 0.287135 & 0.363415 & 0.456137 & 0.491074 & 1.000000 \\
\hline
\end{tabular}

Source: International Monetary Fund data.

Table 6. Real Effective Exchange Rate Correlations of Bangladesh, India, Nepal, Pakistan, and Sri Lanka

\begin{tabular}{lccccc}
\hline & GRBAN & GRIND & GRNEP & GRPAK & GRSRI \\
\hline GRBAN & 1.000000 & & & & \\
GRIND & 0.302231 & 1.000000 & & & \\
GRNEP & 0.273193 & 0.501639 & 1.000000 & & \\
GRPAK & 0.430344 & 0.413592 & 0.385225 & 1.000000 & \\
GRSRI & 0.480120 & 0.332108 & 0.384872 & 0.444670 & 1.000000 \\
\hline
\end{tabular}

Source: International Monetary Fund data. 
Table 7. Correlations of Inflation

\begin{tabular}{lccccccc}
\hline & BANP & BHUP & INDP & MALP & NEPP & PAKP & SRIP \\
\hline & & & & & & & \\
BANP & 1.00 & & & & & & \\
BHUP & 0.06 & 1.00 & & & & & \\
INDP & 0.13 & -0.36 & 1.00 & & & & \\
MALP & 0.15 & -0.05 & 0.41 & 1.00 & & & \\
NEPP & -0.12 & -0.22 & 0.28 & 0.34 & 1.00 & & \\
PAKP & 0.10 & 0.31 & 0.43 & 0.24 & -0.27 & 1.00 & \\
SRIP & 0.27 & -0.23 & 0.41 & 0.46 & 0.05 & 0.30 & 1.00 \\
\hline
\end{tabular}

Table 8. Correlations of Output Growth

\begin{tabular}{lrrrrrrr}
\hline & BANY & BHUY & INDY & MALPY & NEPY & PAKY & SRIY \\
\hline & & & & & & & \\
BANY & 1.00 & & & & & & \\
BHUY & 0.33 & 1.00 & & & & & \\
INDY & 0.07 & -0.08 & 1.00 & & & & \\
MALPY & 0.14 & -0.01 & 0.21 & 1.00 & & & \\
NEPY & 0.02 & -0.33 & -0.13 & -0.39 & 1.00 & & \\
PAKY & -0.30 & -0.07 & 0.17 & -0.07 & 0.06 & 1.00 & \\
SRIY & 0.44 & -0.15 & -0.17 & -0.11 & 0.02 & -0.45 & 1.00 \\
\hline
\end{tabular}


Table 9. Correlations and Standard Deviations of Disturbances (single lag)

\begin{tabular}{crrrrrrr}
\hline & BAN & BHU & MAL & IND & NEP & PAK & SRI \\
\hline & & & & & & & \\
BAN & 1.00 & & & & & & \\
BHU & 0.09 & 1.00 & & & & & \\
MAL & -0.43 & 0.24 & 1.00 & & & & \\
IND & -0.87 & 0.04 & 0.31 & 1.00 & & & \\
NEP & -0.29 & -0.39 & -0.17 & -0.13 & 1.00 & & \\
PAK & -0.34 & -0.41 & -0.54 & 0.56 & -0.02 & 1.00 & \\
SRI & 0.49 & 0.37 & -0.19 & -0.69 & 0.38 & -0.54 & 1.00 \\
& & & & & & & \\
Std. Dev. & 0.006 & 0.009 & 0.016 & 0.014 & 0.014 & 0.018 & 0.010 \\
\hline
\end{tabular}

Table 10. Correlations and Standard Deviations of Disturbances (double lag)

\begin{tabular}{crrrrrrr}
\hline & BAN & BHU & IND & MAL & NEP & PAK & SRI \\
\hline & & & & & & & \\
BAN & 1.00 & & & & & & \\
BHU & 0.03 & 1.00 & & & & & \\
IND & -0.17 & 0.03 & 1.00 & & & & \\
MAL & 0.00 & 0.06 & 0.00 & 1.00 & & & \\
NEP & -0.01 & -0.21 & 0.03 & -0.39 & 1.00 & & \\
PAK & -0.34 & -0.06 & 0.19 & 0.21 & -0.11 & 1.00 & \\
SRI & 0.57 & -0.48 & -0.19 & 0.00 & -0.04 & -0.56 & 1.00 \\
& & & & & & & \\
Std. Dev. & 0.009 & 0.029 & 0.018 & 0.032 & 0.020 & 0.019 & 0.013 \\
\hline
\end{tabular}


Figure 1. Nominal Exchange Rates of the SAARC Member States vis-à-vis the U.S. Dollar
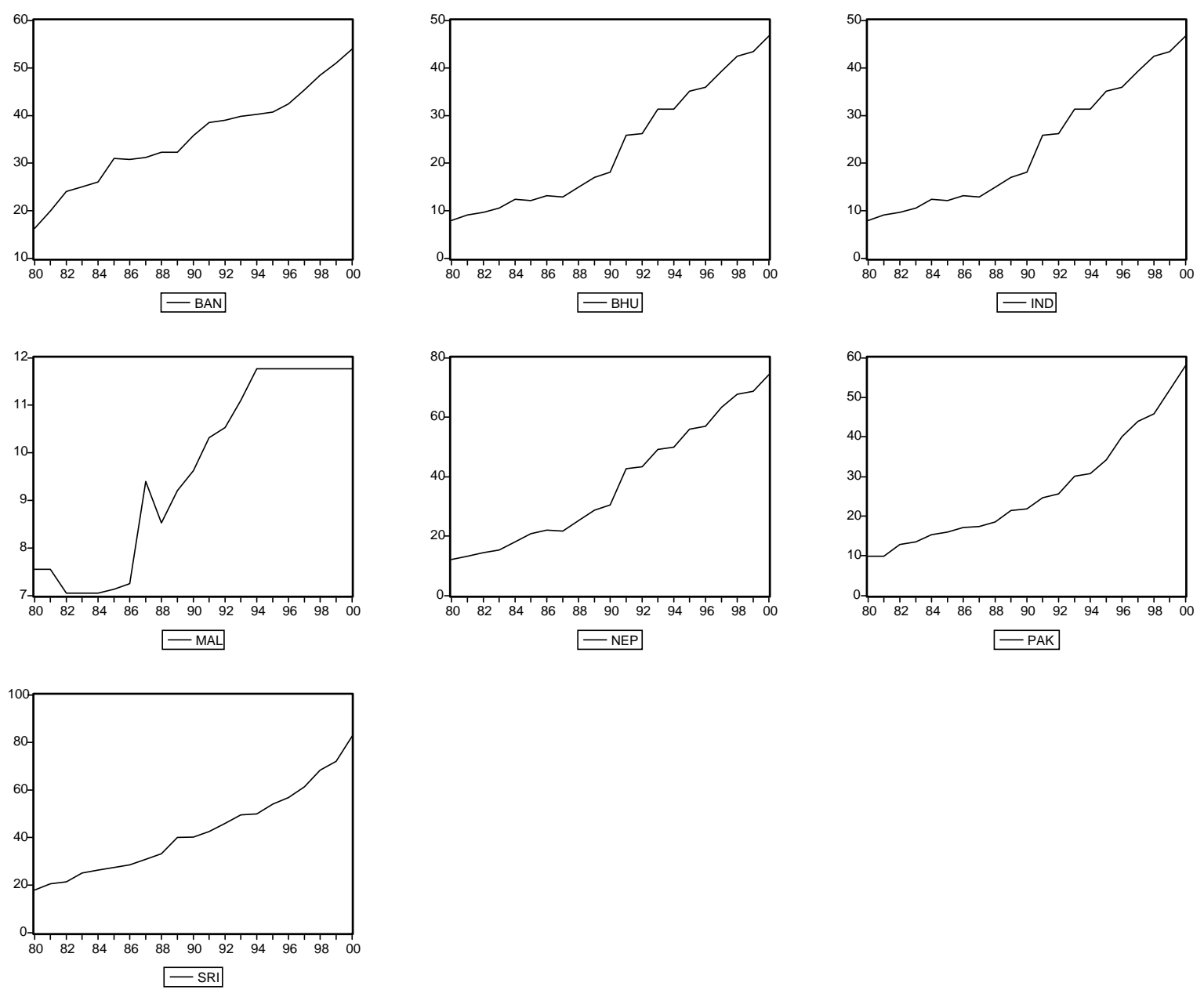

Source: IMF, International Financial Statistics, IFS code ae (end of period exchange rate in units of national currency to the U.S. dollar) for period of 1980-2000. 
Figure 2. Growth Rates of the Nominal Exchange Rates of the SAARC Member States vis-àvis the U.S. Dollar
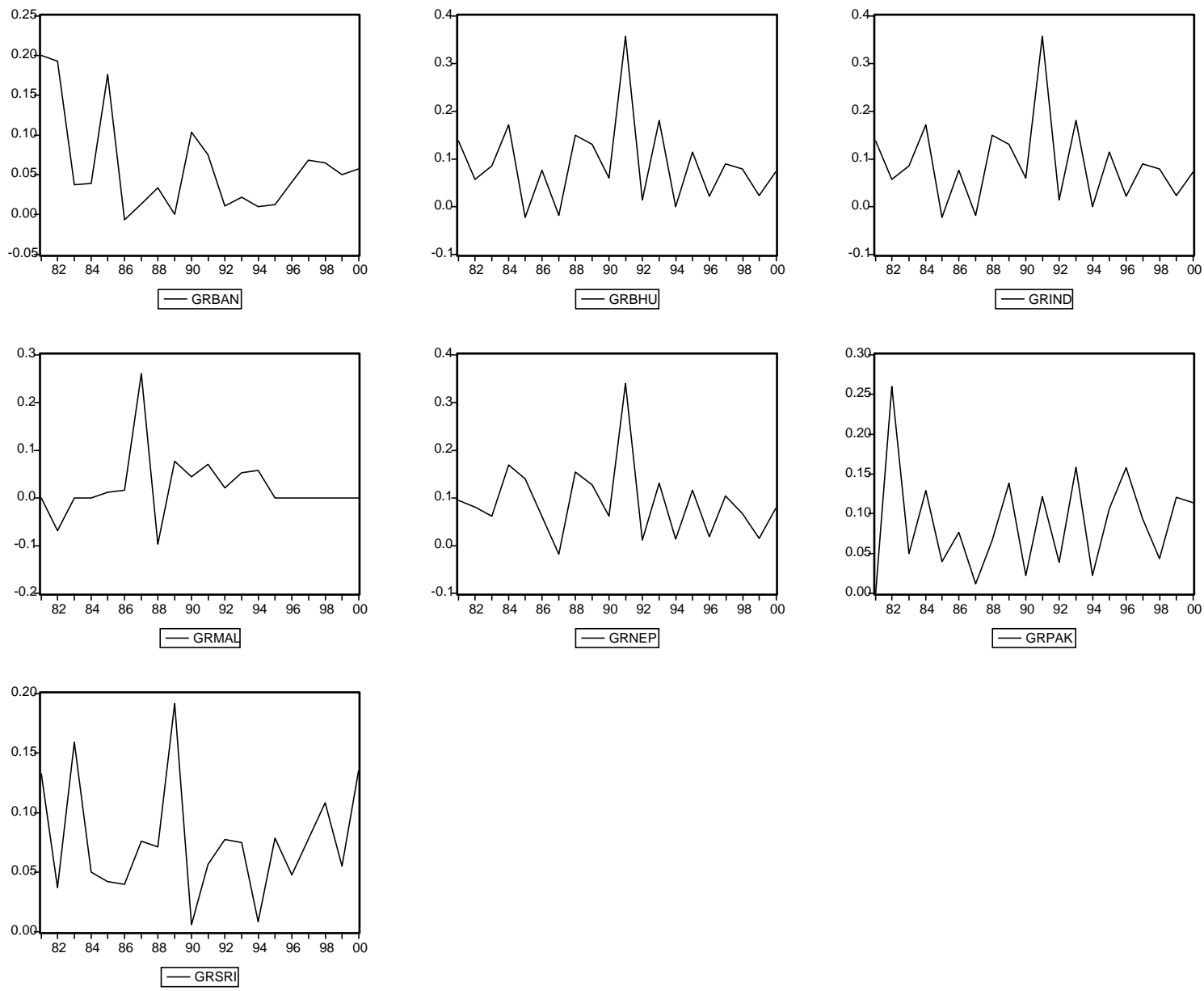

Source: IMF, International Financial Statistics, IFS code ae (end-of-period exchange rate in units of national currency to the U.S. dollar) for period of 1980-2000. 
Figure 3. Nominal Effective Exchange Rates of the SAARC Member States
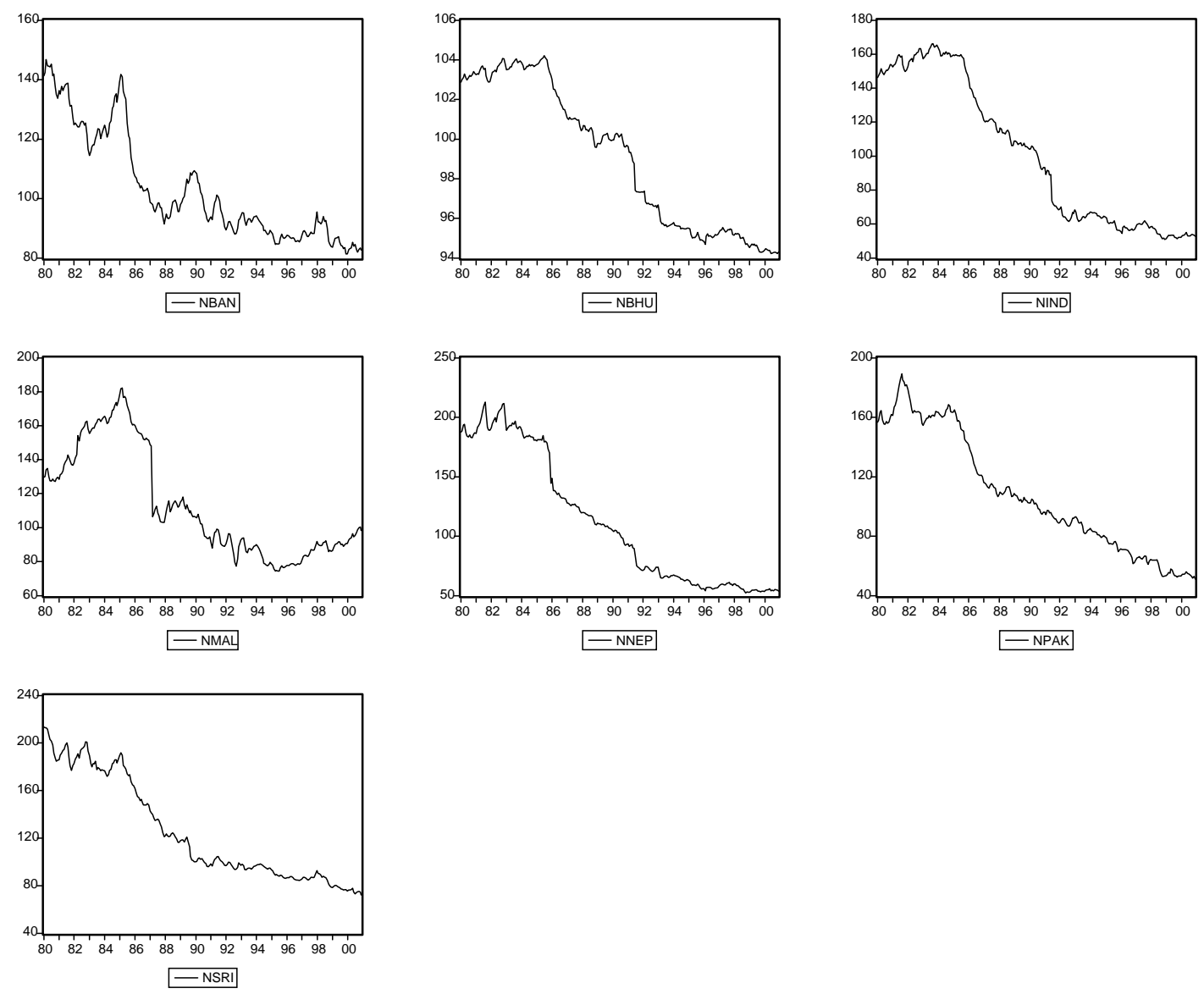

Source: International Monetary Fund data. 
Figure 4. Real Effective Exchange Rates of Bangladesh, India, Nepal, Pakistan and Sri Lanka
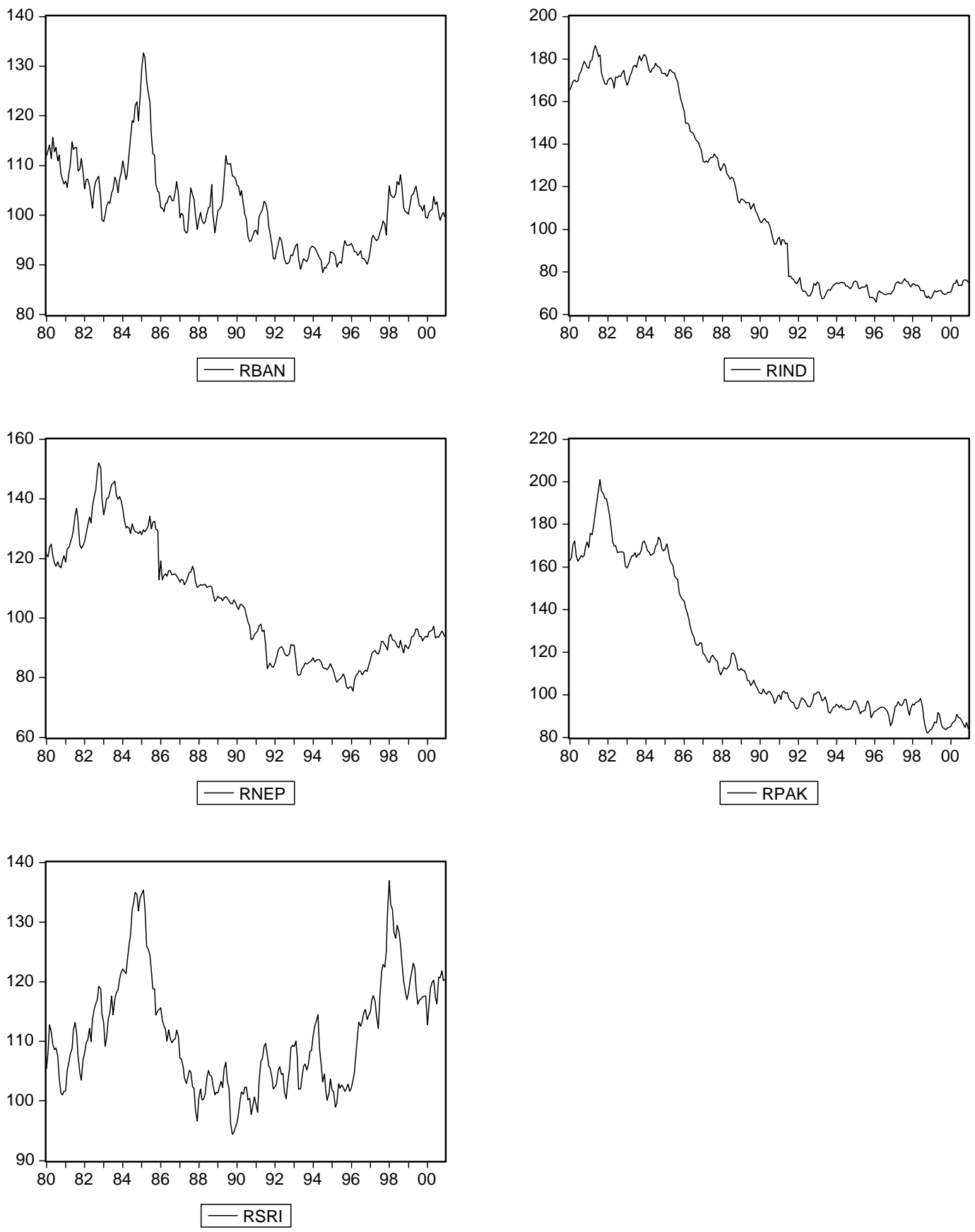

Source: International Monetary Fund data. 
Figure 5. Inflation Rates of SAARC Member States
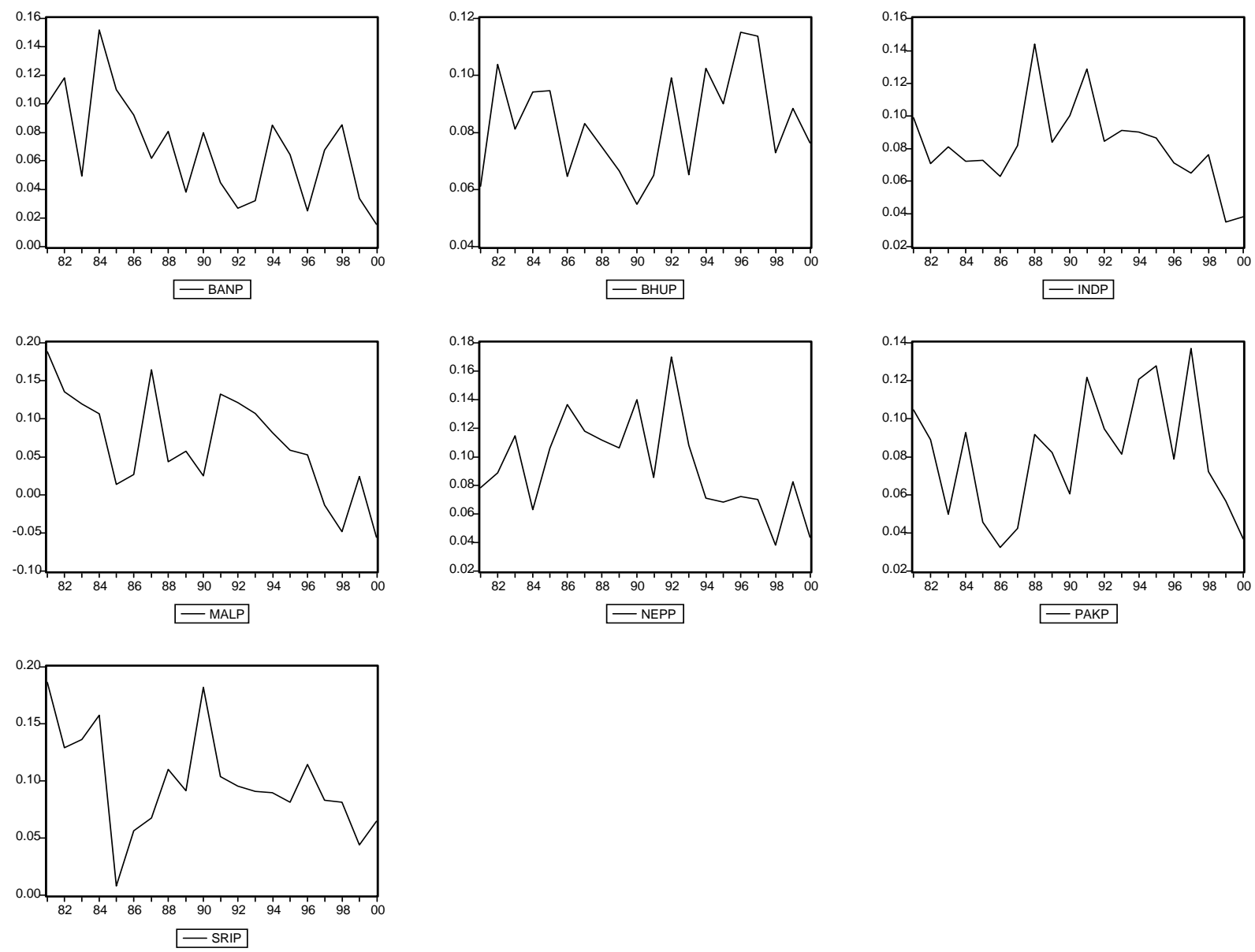

Source: 1. Inflation is taken as the log change of the deflator for Gross Domestic Product (GDP) (IFS code f99bi.p), with exceptions as follows:

1. There is a spike in Bangladeshi inflation during 1989/1990, which is inconsistent with the analysis of Hossain (2002) and IMF; because of this data were taken from the Bangladesh Bureau of Statistics, which had a 95 percent fit for the period of 1986-2000 excluding 1989/90. Thus, movements for those years have been obtained from the Bangladesh Bureau of Statistics.

2. For Maldives, no GDP deflator information was available for 1982 and 1983. Thus, data for GDP were projected from GDP Volume 1994 prices (IFS code 99b.p; 99\% fit) and total fish catch (IFS code 66al; $93 \%$ fit). 
Figure 6. Output Growth Rates of SAARC Member States
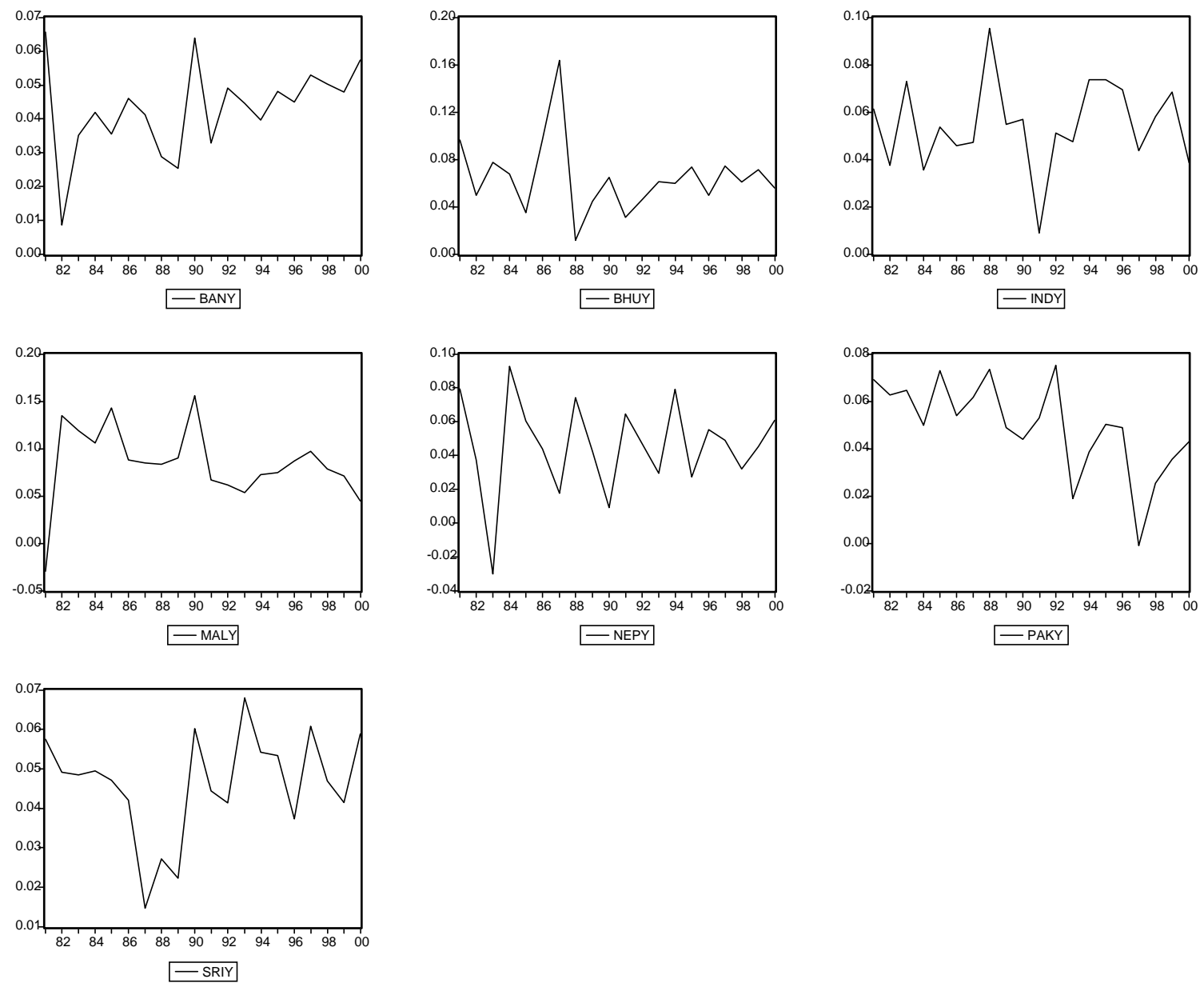

Source: Output growth is taken as the log change in real GDP (IFS code f99b.p), using data from IFS Yearbook 2002, except that data for Sri Lanka for the period 1996-2000 were taken from IFS Yearbook 2001. 


\section{References}

Bayoumi, Tamim, and Barry Eichengreen, 1994, "One Money or Many? Analyzing the Prospects for Monetary Unification in Various Parts of the World," Princeton Studies in International Finance, No. 76.

Bayoumi, Tamim, Barry Eichengreen, and Paolo Mauro, 2000, "On Regional Monetary Arrangements for ASEAN," Journal of the Japanese and International Economics, 14, pp. 121-148.

Bayoumi, Tamim, and Paolo Mauro, 2001, “The Suitability of ASEAN for a Regional Currency Arrangement," World Economy, 24, pp. 933-45.

Bayoumi, Tamim, and Jonathan D. Ostry, 1997, "Macroeconomic Shocks and Trade Flows within Sub-Saharan Africa: Implications for Optimum Currency Arrangements," Journal of African Economies (UK). 6, pp. 412-44.

Cera, Valerie, and Sweta Chaman Saxena, 2000, "What Caused the 1991 Currency Crisis in India,” IMF Working Paper 00/157 (Washington: International Monetary Fund).

Dasgupta, Amit, and Nephil Matangi Maskay, 2003, "Financial Policy Coordination in SAARC; A First Step Toward Monetary Integration in South Asia." Forthcoming in 4(1) of South Asia Economic Journal.

Frankel, Jeffrey A., and Andrew K. Rose, 1998, “The Endogeneity of the Optimum Currency Area Criteria," The Economic Journal, 108, pp. 1009-25.

Hossain, Akhtar, 2002, "Exchange Rate Response to Inflation in Bangladesh,” IMF Working Paper 02/166 (Washington: International Monetary Fund).

Henning, C. Randall, 2002, "East Asian Financial Cooperation,” Policy Analysis in International Economics 68 (Institute for International Economics).

Karras, Georgios, and Houston H. Stokes, 2001, "Time-varying Criteria for Monetary Integration; Evidence from the EMU," International Review of Economics and Finance, 10, pp. 171-85.

Khan, S., and Z.S. Khan, 2003, "Asian Economic Integration: A Perspective on South Asia," Journal of Asian Economics, 13, pp. 767-85.

Maskay, Nephil Matangi, 1998, “A Comment on Empirical Estimation of Patterns of Shocks Utilizing the VAR Methodology on Developing Countries," Journal of Economic Integration, 13(3), pp. 544-48. 
- 2000, “A Cautionary Note in Using Patterns of Shocks to Determine Optimal Exchange Rate Policy; An Exploration of Nepalese and Indian Exchange Rate relations of 1964-1994," Applied Economics, Vol. 32, No. 4, pp. 491-98.

— , 2001, "South Asian Monetary Integration in Light of the Optimum Currency Area Criteria Patterns of Shocks,” South Asia Economic Journal. 2:2,, pp. 203-19.

Masson, Paul, and Catherine Pattillo, 2001, Monetary Union in West Africa (ECOWAS): Is it Desirable and How Could it be Achieved? IMF Occasional Paper No. 204 (Washington: International Monetary Fund).

Masson, Paul R., and Mark P. Taylor, eds., 1993, "Policy Issues in the Operation of Currency Unions" (Cambridge: Cambridge University Press)

Minz, N., 1970, “Monetary Union and Economic Intergeneration” (New York: University Press).

Mundell, Robert, 1961, “A Theory of Optimum Currency Area,” American Economic Review, Vol. 51, pp. 657-65.

Nepal Rastra Bank, 2000, "Feasibility of Using National Currencies in SAARC Trade." _, 2001, SAARCFINANCE seminar conference volume, Issues in Exchange Rate Management (Nepal: Nepal Rastra Bank).

Research and Information System (RIS) for the Non-aligned and Other Developing Countries, 2002, South Asia Development and Cooperation Report 2001/02 (New Delhi).

Romano, Albert, 1970, Applied Statistics for Science and Industry (Boston: Allyn and Bacon Inc.).

Rose, Andrew, 2000, "Currency Unions: Their Dramatic Effect on International Trade," Economic Policy, pp. 8-45.

SAARC, 1985, Charter.

_ 1997/98, "SAARC Vision Beyond the Year 2000: Report of the SAARC Group of Eminent Persons."

— 2002, "Declaration of the $11^{\text {th }}$ Summit in Kathmandu, Nepal," January 6.

—, Website, available on the Internet at: http://www.saarc-sec.org 
Tavlas, George S, 1994, “Theory of Monetary Integration," Open Economies Review (Netherlands), 5, pp. 211-230.

Willett, Thomas D., 2002, “The OCA Approach to Exchange Rate Regimes: A Perspective on Recent Development," in The Dollarization Debate, ed. by James Dean, Dominick Salvatore, and Thomas Willett (Oxford: Oxford University Press).

\section{Data Sources}

International Monetary Fund, International Financial Statistic, (Washington, DC).: various issues.

International Monetary Fund, 2001, Direction of Trade Statistics (Washington, DC).

World Bank, 2002, World Development Indicators 2002 (Washington, DC). , 1997, World Development Indicators 1997 (Washington, DC).

United Nations Development Program, 2002, Human Development Report 2002 (New York).

World Almanac and Book of Facts, 1997 (New York: Press Pub. Co.). 